\title{
Turning Environmental Strategies into Competitive Advantage in the Malaysian Manufacturing Industry: Mediating Role of Environmental Innovation
}

\author{
Tze San Ong ${ }^{1}$, Ah Suat Lee ${ }^{2}$ and Boon Heng Teh ${ }^{3 *}$ \\ ${ }^{1}$ School of Business and Economics, Universiti Putra Malaysia, 43400 Serdang, Selangor, Malaysia \\ ${ }^{2}$ Universiti Tunku Abdul Rahman, 31900 Kampar, Perak, Malaysia \\ ${ }^{3}$ Multimedia University, 63100 Cyberjaya, Selangor, Malaysia
}

\begin{abstract}
The environmental literature has focused on examining how firms leverage environmental innovation to convert environmental challenges into driving forces of competitive advantage. This paper enhances the knowledge on the implementation of environmental strategies in the Malaysian manufacturing industry by examining the impacts of environmental shared vision and environmental strategic focus on competitive advantage in the greening of the industry. The Smart PLS technique was used to analyse data collected from 124 Malaysian manufacturing firms on their environmental strategies as well as their implications for competitive advantage and environmental innovation. The findings suggest that environmental innovation mediates the positive exchange between firms' environmental strategies and competitive advantage. The study provides valuable information for manufacturers in crafting their corporate competitive strategies, policies, and action plans. The direct and indirect roles of environmental innovation in fostering competitive advantage suggest that manufacturers should prioritise their environmental activities by enhancing innovation outcomes to achieve a successful green business status.
\end{abstract}

ARTICLE INFO

Article history:

Received: 23 March 2021

Accepted: 26 April 2020

Published: 30 June 2021

DOI: https://doi.org/10.47836/pjssh.29.2.29

E-mail addresses:

tzesan@upm.edu.my (Tze San Ong)

cristallee08@gmail.com (Ah Suat Lee)

bhteh@mmu.edu.my (Boon Heng Teh)

$*$ Corresponding author
Keywords: Environmental innovation, environmental shared vision, environmental strategies, environmental strategic focus, manufacturing industry, Malaysia

\section{INTRODUCTION}

Due to proliferating worldwide demand for environmental protection, environmental innovation (EI) has become the major vehicle driving economic development 
(Chang, 2011). Concurrently, more stringent environmental protection regulations have been enforced on businesses, significantly reshaping the nature of business competition into an environment-oriented one. Consumers, too, exhibit trends of increasing demand for green products that generate less harm to the environment (Ong et al., 2019). In response to these changes, governmental bodies and business organisations all over the world are proactively implementing environmental protection actions in an attempt to avoid and solve environmental degradation issues (Nishimura, 2014; Ong et al., 2019; Wiengarten et al., 2013). Companies which are proactive in managing environmental issues surrounding their business are likely to gain benefits (e.g. differentiating their products from competitors, lowering their cost structure as a result of waste reductions), which represent valuable opportunities to gain competitive advantage (CA) (Ong et al., 2020; Porter, 1981; Porter \& van der Linde, 1995). In relation to this notion, EI is the implementation of new products, processes, or methods to reduce environmental impacts and satisfy users' needs, which subsequently leads to higher competitiveness as well (Cheng \& Shiu, 2012; OECD, 2005; Schiederig et al., 2012). Following this reasoning, it is plausible that EI acts as the agent that enables environmental management practices to foster CAs.

Barney (1991) and Porter (1980) refer to CA as the state where a company's competitive strategies are not replicable by other companies operating in the same market. In this regard, EI reflects the incorporation of environmental solutions into product design as well as the production process, which provides the basis for differentiation that forms a CA (Chen et al., 2006; Hart, 1995). Besides improving efficiency (Porter \& van der Linde, 1995), EIs enhance product value, thereby validating the trade-off between the investment costs and benefits of environmental solutions. In view of these strategic benefits, EIs are at the top of the corporate agenda in the competitive global environment. Indeed, most companies are increasingly prepared to invest more resources into such innovation. By focusing on EI, companies can mitigate conflicts between environmental protection investments and financial performance, enjoying a win-win outcome in both aspects. Therefore, companies are now aware that devoting capital to environmental protection strengthens their EI capabilities, which limits potential legal liabilities, improves operating efficiency, and expands markets for green products (Chang, 2011; Chen, 2008).

The resource-based view of the firm (RBV) asserts that firms' competitive advantage and performance are highly influenced by the resources and capabilities owned by them (Barney, 1991, 2001). As such, the RBV regards firm performance as attributed to resources having a differential level of efficiencies by the firms (Barney, 1991; Hart \& Dowell, 2011; Peteraf \& Barney, 2003). Following a similar idea of the RBV, Hart (1995, p. 991) illustrated that "it is likely that strategy and competitive 
advantage in coming years will be rooted in capabilities that facilitate environmentally sustainable economic activity".

Notably, the literature on the natural resource-based theory (NRBV) has established EI as the underlying reason for companies' ability to improve performance through environmental management. Environmental management encompasses creating, organising, monitoring, and handling environmental issues related to corporate activities, with the objective of mitigating adverse environmental impacts (Dost et al., 2019). Firms with environmental management proactively place environmental considerations at the centre of their strategic planning and decision making, in addition to cultivating a shared environmental vision among their employees. Consequently, these companies are likely to develop and utilise innovations to make ongoing improvements to their environmental efforts, leading to possibilities of new markets, better cost structures, and superior financial performance (Chang, 2011; Walley \& Whitehead, 1994).

In line with these propositions, numerous studies have found support for the positive effect of environmental strategies on EI (Fernando et al., 2019; Ong et al., 2019, 2020). Nevertheless, the literature lacks empirical studies that link firms' environmental strategies involving EI to CA. Additionally, apart from Grekova et al. (2013), scholars have devoted limited attention to the role of EI in the link between environmental performance and firm performance. In view of these research gaps, this study investigated EI as the mediating factor that explains the impact of two environmental strategies (environmental strategic focus and environmental shared vision) on CA. This research included firm size as the control variable as it has functioned as a robust control variable in studies explaining corporate environmental management and business performance (Buysse \& Verbeke, 2003; Guenther \& Hoppe, 2014; Ong et al., 2020). This is due to large firms tend to invest more extensively in environmental management due to better availability of resources (Judge \& Douglas, 1998) and also greater need to protect their reputation, hence are more likely to gain competitive advantage (Coombs \& Bierly, 2006).

The rest of this paper is organised as follows: Section 2 presents a review of literature; Section 3 explains the hypotheses development; Section 4 describes the research methodology; Section 5 reports the empirical findings; Section 6 provides a discussion of the findings; Section 7 puts forth the implications and conclusions of the study; and Section 8 addresses the limitations of study with suggestions for future research.

\section{LITERATURE REVIEW}

\section{Environmental Strategic Focus}

The potential of environmental sustainability initiatives to enhance firm value is highly dependent on the extent they are considered strategic priorities (Porter \& Kramer, 2006). Taking this into account, an environmental strategic focus (ESF) conceptualises the 
extent to which environmental considerations are incorporated in corporate strategy development (Banerjee, 2002). The ESF enables a firm to align the essentials of its environmental strategies with its company and business strategies (Banerjee, 2002; Banerjee et al., 2003; Judge \& Douglas, 1998). Thus, the ESF enables corporate management to adopt an integrated view of their environmental sustainability responsibilities and shareholders' financial performance requirements in strategic planning and decision making.

\section{Environmental Shared Vision}

An organisational shared vision refers to the collective aims and ambitions of the members (Tsai \& Ghoshal, 1998) that specify the future direction of a company (Larwood et al., 1995). That is, an organisational vision is self-identified and shared by organisational members (O’Connell et al., 2011; Zaccaro $\&$ Banks, 2001). Consistent with this, an environmental shared vision (ESV) is defined in this study as an environmental strategic goal that is collectively adopted as a core value among organisational members (Chen et al., 2015; Larwood et al., 1995; Tsai \& Ghoshal, 1998). Corporate environmental studies have lately extended the concept of a shared vision to environmental protection goals (Aragón-correa et al., 2008; Chen et al., 2015). For example, Chen et al. (2015) referred to a green shared vision as a collection of common environmental goals and ambitions that have been intensely embraced by members of a company. Thus, adding to the key attributes of a shared vision, an ESV conceptually embodies environmental protection goals.

\section{Environmental Innovation}

Scholars have commonly used three interchangeable terms to represent environment-related innovation: EI (Cortez \& Cudia, 2010; Forsman, 2013); eco-innovation (Arundel \& Kemp, 2009; Cheng et al., 2014; Kesidou \& Demirel, 2012; Sezen \& Çankaya, 2013), and green innovation (Chang, 2011; Chen et al., 2008; Chen et al., 2006; Chiou et al., 2011). Upon analysing the definitions of environmentrelated innovation, Schiederig et al. (2012) concluded that three core aspects of innovation are generally included in almost all environmental researchers' definitions: (i) reference to a product, process, or service methods; (ii) incorporation of market orientation to satisfy needs or stay competitive; (iii) incorporation of the environmental objective to reduce negative impact. Overall, the definitions of EI integrate both economic and ecological aims (Schiederig et al., 2012).

We defined EI as the implementation of new products, processes, or methods that reduce environmental impacts and better satisfy users' needs, thereby improving competitiveness (Cheng \& Shiu, 2012; OECD, 2005; Schiederig et al., 2012). In line with this definition, in this study, EI was represented as technical innovation, which is the firms' technical knowledge and knowhow that has been successfully implemented 
and has improved processes and products. Specifically, we considered EI to be reflected by two aspects of technical innovation: environmental product innovation (ENP) and environmental process innovation (ENC) (Armbruster et al., 2008; Cheng \& Shiu, 2012; OECD, 2005; Rennings et al., 2006; Schiederig et al., 2012).

ENP refers to the launching of a new service or product with significantly enhanced features that reduce adverse environmental effects associated with its use (Cheng \& Shiu, 2012; OECD, 2005; Rennings et al., 2006). Similarly, ENC refers to the adoption of a substantially improved or new method that decreases the harmful environmental impacts of manufacturing processes (Cheng \& Shiu, 2012; OECD, 2005; Rennings et al., 2006). Consequently, ENP equips firms with unique green products that are appealing to customers in the green market while ENC fosters production competencies that engender resource efficiency and better product quality. Given that superior products and processes exert the strongest influence on firms' competitive position, the focus on product and process aspects enables an outcome approach in examining firms' EI. That is, both environment-related product and process improvements contribute to firms' ability to compete (Chen et al., 2006; Chiou et al., 2011; Forsman, 2013). As such, this research argued for the need to empirically examine how EI strengthens two major indicators of economic performance: $\mathrm{CA}$ and financial performance.

\section{Competitive Advantage}

CA refers to the market situation engaged by a company following its successful strategy that is not imitable by competitors (Barney, 1991). Peteraf and Barney (2003, p. 314) similarly conceptualised it as the "ability to create relatively more economic value in comparison to marginal competitors either through superior differentiation or having lower cost".

Studies adopting the resource-based view explain CA through the net benefits approach, whereby larger net benefits indicate more efficient use of firm resources. However, the resource-based theory (Barney, 1991) does not argue for the inherent link between a firm's CA and its ability to achieve superior profitability. Scholars stress that not all profits generated by a firm are reflected in its accounting-based or marketbased performance measures (Coff, 1999; McCarthy et al., 2015; Newbert, 2007). Instead, superior firm performance is only achievable when firms make effective use of their CAs (Ma, 2000; McCarthy et al., 2015). On top of the CA factor, firms' profitability is also influenced by its distribution of residual net benefits among various resources providers (Coff, 1999; Peteraf, 1993), including debt providers, equity providers, and employees. Thus, it is crucial to differentiate the construct of CA from firm performance in empirical studies testing sources of firm competitiveness (McCarthy et al., 2015; Sigalas \& Economou, 2013; Sigalas et al., 2013), so as to eliminate additional factors that potentially affect superior firm performance besides CA. 


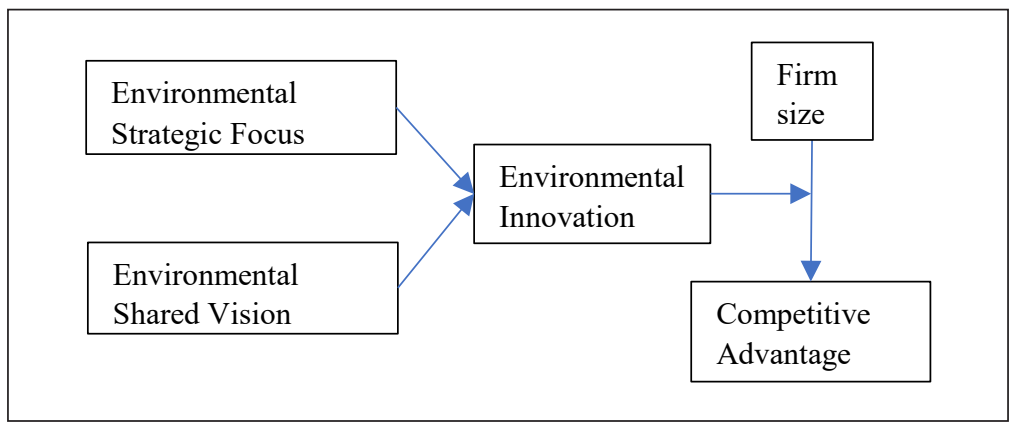

Figure 1. Research framework

\section{THEORETICAL FRAMEWORK AND HYPOTHESIS DEVELOPMENT}

In this section, we developed our overall research model by first exploring the ESF's relationship with EI before examining the link between ESV and EI. Subsequently, we evaluated the relationship between EI and CA. Finally, we tested the mediating role of EI between the two environmental strategies and CA. Firm size is included as the control variable on competitive advantage. Figure 1 presents the conceptual model of this study.

\section{Environmental Strategic Focus (ESF) and Environmental Innovation}

Companies with an ESF regard environmentalism as the underlying factor driving new product development. These companies proactively take actions to incorporate environmental considerations into their products and manufacturing processes to mitigate their environmental damage (McCloskey \& Maddock, 1994; Ong et al., 2020). In particular, an ESF within a firm is reflected by top management's commitment to environmental protection, a functional environmental interface, and explicit environmental policies. These elements precede firms' environmentally responsive behaviour in the development of new products (Pujari et al., 2004), which ultimately strengthens firms' ability to generate new goods with less adverse environmental impacts. This enhances firms' EI. Further, an ESF is positively associated with the allocation of resources for environmental protection, which translates into investments in cleaner technologies. Such technologies enable a firm to radically change its operations into more environmentally friendly ones (Shrivastava, 1995; Ong et al., 2020), resulting in the minimisation of pollution and waste from its manufacturing processes (Klassen \& Whybark, 1999). This contributes to firms' EI. Thus, we postulated the following hypothesis:

H1: Environmental strategic focus (ESF) is positively associated with environmental innovation (EI).

\section{Environmental Shared Vision (ESV) and Environmental Innovation (EI)}

According to the shared cognition literature, a shared vision fosters team dynamics 
(Pearce \& Ensley, 2004) in the form of team belief in success, teamwork, and intra-team helping behaviours, which in turn drive firms' innovative performance. Consequently, high team dynamics cultivate working groups that are not just rich in environment-related ideas but are also highly enthusiastic about EIs. Moreover, a shared vision results in higher resource exchange and integration among organisational members, which also facilitates the innovation process.

Taken together, an ESV would nurture the drivers of EI, namely environmental learning, environmental knowledge and skills, green creativity, team dynamics, and market information generation. We, therefore, theorised that the higher the degree of ESV in a firm, the greater its EI. To empirically validate this notion, the following hypothesis was developed:

$\mathrm{H} 2$ :Environmental shared vision (ESV) is positively associated with environmental innovation (EI).

\section{Environmental Innovation (EI) and Competitive Advantage (CA)}

The NRBV (Hart, 1995; Hart \& Dowell, 2011) emphasises that EI contributes to a firm's CA, as this capability is rare, valuable, firm-specific, and non-imitable by competitors (Barney, 1991), in addition to being socially complex and path-dependent (Hart, 1995; Sharma \& Vredenburg, 1998). Empirical studies have consistently validated this positive association between EI and CA. In particular, both environmental product and process innovations have been reported to positively affect CA in firms in Taiwan (Chen et al., 2006; Chiou et al., 2011), China (Liao, 2016), and Turkey (Küçükoğlu \& Pınar, 2015). Thus, in line with the NRBV literature and empirical evidence that both environment-related product and process innovations contribute to firms' ability to compete (Chen, 2006; Chiou et al., 2011; Forsman, 2013), it was hypothesised that:

H3: E nvironmental innovation (EI) is positively associated with competitive advantage (CA).

\section{Mediation Effect of Environmental Innovation (EI)}

EI is believed to be the key factor underpinning the positive association between proactive environmental practices and firm performance (Hart, 1995; Porter \& van der Linde, 1995; Sharma \& Vredenburg, 1998). Environmental researchers have postulated that investments in environmental management inflict net costs and lose cost advantages if companies exhaust opportunities to gain net benefits from environmental practices (Schaltegger \& Synnestvedt, 2002). As such, firms' choice of strategies for environmental improvement is critical in turning environmental strategies into CA (King \& Lenox, 2001; Reinhardt, 1998). Specifically, Orsato (2006) argued that firms implementing an EI strategy are more likely to gain competitive strengths from environmental practices. For example, a product differentiation advantage is attainable through innovative changes in product design and materials that improve 
green features and functionality. Likewise, the implementation of green process improvements creates a cost advantage. It can thus be surmised that the potential to gain competitiveness from environmental performance is contingent on firms' ability to convert their environmental strengths into green products and processes through innovation.

Consistent with this, the NRBV (Hart, 1995; Hart \& Dowell, 2011) also posits that innovation must be an outcome of environmental strategies (i.e. ESF and ESV) in order to achieve superior CA. Hence, we proposed the mediating role of EI in the following hypothesis:

H4a: Environmental innovation (EI) mediates the influence of environmental strategic focus (ESF) on competitive advantage (CA).

H4b: Environmental innovation (EI) mediates the influence of environmental shared vision (ESV) on competitive advantage (CA).

\section{Firm Size as the Control Variable}

Firm size is included in the research model as the control variable. Meta study reported the significant influence of firm size on innovation (Camisón-Zornoza et al., 2004). Larger size firms are more advantageous in terms of economies of scale, advertising, and new product developments that could serve as sources of firm performance and competitive advantage (Coombs \& Bierly, 2006). The natural logarithm of a firm's number of employees would represent the measure of size.

\section{RESEARCH METHODOLOGY}

\section{Questionnaire}

Data was collected using a questionnaire that was sent to targeted companies via postal mail and, in some cases, via email. Each hardcopy questionnaire form was mailed with a cover letter and a stamped return envelope. Multiple phone calls were made to the respondents as a follow-up measure to increase the response rate and to persuade those who had not returned their questionnaire. A replacement questionnaire was provided to those who had missed the previously sent one.

\section{Measurement Scales of Study}

The questionnaire comprised five sections; one solicited the companies' details while four measured the study variables using scales adapted from previous literature. The scales for ESF ( 7 items) and ESV (4 items) were adapted from Banerjee et al. (2003) and Chen et al. (2015). CA's measure (5 items) was adapted from Karagozoglu and Lindell (2000). EI's scale had 11 items adapted from Chen et al. (2006), Chen (2008), and Chiou et al. (2011). All items were rated on a 5-point Likert scale, from ' 1 -strongly disagree' to '5-strongly agree'.

\section{Sample}

All ISO 14001 Environmental Management System (EMS) certified manufacturers in Malaysia (a total of 483 at the point of data collection) were included as the study population. Despite not mandatorily required to by Malaysian regulations, these companies have channelled substantial 
resources into certifying their EMS. Such an investment signals to stakeholders these firms' commitment to and assurance of environmental protection. As such, these manufacturers are likely to be highly proactive in implementing environmental practices.

\section{Pilot Test}

The questionnaire was first pre-tested by six academic experts before being pilot-tested among 20 companies. The questionnaire was then revised according to the comments of the experts and pilot test respondents. 124 survey responses were gathered from the 483 distributed questionnaires. This yielded a response rate of 25.7 percent, which is comparable to other firm-based survey studies in Malaysia (Eltayeb et al., 2011; Lee et al., 2013). Moreover, a sample size of 124 companies was deemed adequate for partial least squares structural equation modelling (PLS-SEM) analysis as it fell within the acceptable sample size range (Hair et al., 2017).

\section{Non-response Bias and Common Method Bias}

The findings from Harmon's single-factor indicated that 36.99 percent of the total variance was explained by the first factor, hence common method bias was not a risk in this study (Podsakoff et al., 2003). All constructs were also subjected to an independent $t$-test to assess whether the data gathered was significantly different between the 106 late answered companies and the 18 early answered companies. Levene's test statistic reported a non-significant result, proving that non-response bias was negligible (Gastwirth et al., 2009).

\section{RESULTS}

\section{Descriptive Results}

Table 1 describes the companies' profiles. The main activities of these firms included chemicals, chemical products, and manmade fibres $(n=16,13 \%)$, rubber and plastic $(n=18,15 \%)$, motor vehicles, transport equipment, and basic metal products $(n=22$, $18 \%)$, electrical and electronics $(n=29$, $23 \%)$, and others $(n=39,31 \%)$. A majority of the sampled firms ( $n=108,107 \%)$ had more than 50 percent Malaysian ownership. Age and size statistics indicate that most of the sampled firms had well-established large-scale manufacturing operations aged between 21 and 40 years $(n=58,46 \%)$ and more than 40 years $(n=53,43 \%)$. Only a minority were less than 20 years of age $(\mathrm{n}=13,11 \%)$. The firms' full-time staff force size was taken as a proxy for their size. Since most firms were large, they employed 200 to 500 employees $(n=41,33 \%)$ or more than 500 employees $(n=31,25 \%)$. The remaining smaller firms had a workforce of fewer than 200 employees $(n=52,42 \%)$ (SME Corporation Malaysia, n.d.). In terms of international involvement, a majority of the respondent firms had a considerable proportion of their products exported: 56 firms $(45 \%)$ had 10 to 50 percent of their products sold to overseas markets, while 21 firms (17\%) had more than half of their products exported. The remaining firms $(n=47,38 \%)$ had no exports. 
Table 1

Profile of respondent companies

\begin{tabular}{|c|c|c|}
\hline Description & Frequency & $\%$ \\
\hline \multicolumn{3}{|l|}{$\mathrm{N}=124$} \\
\hline \multicolumn{3}{|l|}{ Companies' main activities } \\
\hline $\begin{array}{l}\text { Communication equipment and radio, television, electrical } \\
\text { machinery, optical equipment. }\end{array}$ & 29 & $23 \%$ \\
\hline $\begin{array}{l}\text { Fabricated metal products, basic metals, motor vehicles, and } \\
\text { transport equipment. }\end{array}$ & 22 & $18 \%$ \\
\hline Plastic and rubber products & 18 & $15 \%$ \\
\hline Chemicals, chemical products, and man-made fibres & 16 & $13 \%$ \\
\hline Others & 39 & $31 \%$ \\
\hline \multicolumn{3}{|l|}{ Employees No. } \\
\hline Less than 200 (Small and medium size) & 52 & $42 \%$ \\
\hline Less then 200 & 52 & $42 \%$ \\
\hline Between 200 and 500 (large size) & 41 & $33 \%$ \\
\hline Above 500 (large size) & 31 & $25 \%$ \\
\hline
\end{tabular}

\section{Partial Least Squares Structural Equation Modelling (PLS-SEM) Analysis Results}

To perform PLS-SEM analysis, SmartPLS Version 3.2.3 (Hair et al., 2016) was employed to assess the measurement model and structural model.

\section{Assessment of Measurement Model}

As per Hair et al. (2016), the measurement model confirms the reliability and validity of the constructs before testing the hypotheses. In this study, EI was a second-order reflective construct; therefore, the two-stage method was employed to evaluate the reliability and validity of EI. Specifically, product innovation and process innovation were first assessed separately with all other firstorder constructs in the model (Bradley \& Henseler, 2007; Henseler et al., 2015).
The results of internal consistency reliability and convergent validity are illustrated in Table 2. The average variance extracted (AVE) for all constructs ranged from .557 to .699 , while CRs ranged from .862 to .923 and Cronbach's alpha values ranged from .738 to .892 . As the thresholds for AVE and reliability are .5 and .7 respectively, the constructs in this study demonstrated satisfactory convergent validity and internal consistency reliability (Hair et al., 2013).

Fornell and Larcker's (1981) criterion was used to evaluate the constructs' discriminant validity, which indicates that each construct is different from the other (Hair et al., 2013). To establish discriminant validity, the square root of each variable's AVE should be higher than the squared correlations between the variable and other 
Table 2

Convergent validity

\begin{tabular}{|c|c|c|c|c|c|}
\hline \multicolumn{6}{|c|}{ First Order Construct } \\
\hline Items & Loadings & Constructs & AVE & CR & $\mathbf{C A}$ \\
\hline CA1 & 0.784 & \multirow{5}{*}{$\begin{array}{l}\text { Competitive } \\
\text { advantage (CA) }\end{array}$} & \multirow[t]{5}{*}{.570} & \multirow[t]{5}{*}{.868} & \multirow[t]{5}{*}{.809} \\
\hline CA2 & 0.791 & & & & \\
\hline CA3 & 0.617 & & & & \\
\hline CA4 & 0.749 & & & & \\
\hline CA5 & 0.817 & & & & \\
\hline EF1 & 0.799 & \multirow{5}{*}{$\begin{array}{l}\text { Environmental } \\
\text { strategic focus (ESF) }\end{array}$} & \multirow[t]{5}{*}{.557} & \multirow[t]{5}{*}{.862} & \multirow[t]{5}{*}{.802} \\
\hline EF2 & 0.700 & & & & \\
\hline EF3 & 0.751 & & & & \\
\hline EF6 & 0.713 & & & & \\
\hline EF7 & 0.764 & & & & \\
\hline EV1 & 0.728 & \multirow{4}{*}{$\begin{array}{l}\text { Environmental shared } \\
\text { vision (ESV) }\end{array}$} & \multirow[t]{4}{*}{.582} & \multirow[t]{4}{*}{.847} & \multirow[t]{4}{*}{.764} \\
\hline EV2 & 0.732 & & & & \\
\hline EV3 & 0.791 & & & & \\
\hline EV4 & 0.798 & & & & \\
\hline ENC1 & 0.855 & \multirow{5}{*}{$\begin{array}{l}\text { Process Innovation } \\
\text { (ENC) }\end{array}$} & \multirow[t]{5}{*}{.699} & \multirow[t]{5}{*}{.920} & \multirow[t]{5}{*}{.892} \\
\hline ENC2 & 0.806 & & & & \\
\hline ENC4 & 0.796 & & & & \\
\hline ENC5 & 0.868 & & & & \\
\hline ENC6 & 0.853 & & & & \\
\hline ENP1 & 0.820 & \multirow{4}{*}{$\begin{array}{l}\text { Product Innovation } \\
\text { (ENP) }\end{array}$} & \multirow[t]{4}{*}{.561} & \multirow[t]{4}{*}{.836} & \multirow[t]{4}{*}{.738} \\
\hline ENP2 & 0.705 & & & & \\
\hline ENP4 & 0.737 & & & & \\
\hline ENP7 & 0.731 & & & & \\
\hline \multicolumn{6}{|c|}{ Second Order Construct Loadings } \\
\hline ENC & 0.928 & \multirow{2}{*}{$\begin{array}{l}\text { Environmental } \\
\text { Innovation (EI) }\end{array}$} & \multirow[t]{2}{*}{.856} & \multirow[t]{2}{*}{.923} & \multirow[t]{2}{*}{.832} \\
\hline ENP & 0.923 & & & & \\
\hline
\end{tabular}

Table 3

Discriminant validity

\begin{tabular}{clccccc}
\hline S No & \multicolumn{1}{c}{ Constructs } & $\mathbf{1}$ & $\mathbf{2}$ & $\mathbf{3}$ & $\mathbf{4}$ & $\mathbf{5}$ \\
\hline 1 & Competitive Advantage & .755 & & & & \\
2 & Environmental Innovation & .614 & .710 & & & \\
3 & Environmental Shared Vision & .545 & .552 & .764 & & \\
4 & Environmental Strategic Focus & .685 & .693 & .571 & .724 & \\
5 & Firm size & -.031 & -.182 & -.163 & -.147 & 1 \\
\hline
\end{tabular}

Note: Diagonals (italic) show the square roots of AVE. The rest are Pearson's correlation values. 
variables (Chin, 1998; Fornell \& Larcker, 1981). As shown in Table 3, the diagonal square roots of AVE were greater than the off-diagonal correlations. Therefore, discriminant validity was fulfilled in the study model.

\section{Assessment of Structural Model}

After evaluating the measurement model, we subsequently tested the structural model to confirm the study hypotheses. Since PLS-SEM does not generate inferential statistics on model fit and parameters, the bootstrapping procedure was carried out with 5000 resamples using the SmartPLS 3.0 software (Chin, 2010). Bootstrapping produces statistics on standard path coefficients, standard errors, and t-values, which allows the evaluation of the significance of each hypothesis (Hair et al., 2017).

\section{Path Coefficients of Direct Relationships}

Table 4 presents the results of direct path coefficients. ESF reported a significant positive relationship with EI $(\beta=.561$, $p=.000$ ), supporting H1. H2 was also supported by the significant positive link between ESV and EI $(\beta=.231, p=.010)$. Likewise, H3 was significant as EI was found to exert a positive influence on CA $(\beta=.629, p=.000)$. We also included firm size as a control variable in the analysis. However, firm size did not have a significant effect on $\mathrm{CA}(\beta=.083, p=.000)$.

Henseler et al. (2009) posit that the predictive power of the structural model relies on its coefficient of determination $\left(R^{2}\right)$ value. The $R^{2}$ value must be substantial for the model to exhibit explanatory power. The $R^{2}$ values were .517 for EI and .340 for CA, suggesting that the exogenous variables (ESV, ESF, and EI) in this study satisfactorily explained both the endogenous variables.

Based on the effect size $\left(\mathrm{f}^{2}\right)$ in Table 4 , it can be seen that ESF had a large effect and ESV had a small effect on EN. Lastly, EN had a large effect on CA.

The predictive relevance, $\mathrm{Q}^{2}$, value is evaluated using the blindfolding procedure, where structural models with a $\mathrm{Q}^{2}$ greater than zero are considered to have predictive relevance (Hair et al., 2016). Table 5 shows the $\mathrm{Q}^{2}$ values for all the endogenous constructs, which establish that the model has predictive relevance.

Table 4

Hypothesis testing

\begin{tabular}{lllllllll}
\hline Hypothesis & \multirow{2}{*}{ Path } & $\begin{array}{c}\text { Standard } \\
\text { beta }\end{array}$ & $\begin{array}{c}\text { Standard } \\
\text { Error }\end{array}$ & T-value & P-value & Results & $\mathbf{f}^{2}$ & $\mathbf{R}^{2}$ \\
\hline $\mathrm{H} 1$ & $\mathrm{ESF} \rightarrow \mathrm{EI}$ & .561 & .076 & $7.341^{* * *}$ & .000 & Supported & .440 & .517 \\
$\mathrm{H} 2$ & $\mathrm{ESV} \rightarrow \mathrm{EI}$ & .231 & .09 & $2.56^{* *}$ & .010 & Supported & .075 & - \\
$\mathrm{H} 3$ & $\mathrm{EN} \rightarrow$ CA & .629 & .055 & $11.447^{* * *}$ & .000 & Supported & .622 & .340 \\
$\mathrm{CV}$ & $\mathrm{FS} \rightarrow$ CA & .083 & .065 & 1.29 & .197 & Unsupported & .011 & \\
\hline
\end{tabular}

Note: $* * \mathrm{p} \leq .01, * * * \mathrm{p}<.0001 . \mathrm{CV}=\mathrm{control}$ variable; $\mathrm{CS}=$ firm size; $\mathrm{ESF}=$ environmental strategic focus; $\mathrm{ESV}=$ environmental shared vision; $\mathrm{EI}=$ environmental innovation; $\mathrm{CA}=$ competitive advantage 
Table 5

Predictive relevance $\left(Q^{2}\right)$

\begin{tabular}{llc}
\hline No & Construct & $\mathbf{Q}^{\mathbf{2}}$ \\
\hline 1 & Competitive advantage & .356 \\
2 & Environmental Innovation $_{-}$ & .364 \\
3 & Environmental Shared Focus & .330 \\
4 & Environmental Shared vision & .313 \\
5 & Firm Size & 1 \\
\hline
\end{tabular}

\section{Mediation Analysis Results}

The bootstrapping function of SmartPLS 3.0 was again employed to determine the mediating effect of EI between environmental strategies and CA. Table 6 illustrates that both indirect effects had beta values ranging from .353 to .146 and t-values ranging from 5.920 to 2.337 , thereby establishing the positive mediating effect of EI and supporting $\mathrm{H} 4 \mathrm{a}$ and $\mathrm{H} 4 \mathrm{~b}$.

\section{DISCUSSION}

Our findings reveal the vital role of EI as a mediating variable that converts the values of environmental strategies into CAs for manufacturers that implement proactive environmental management. Proactive environmental strategies signify firms' successful mitigation of environmental damages, such as solid waste, wastewater, air emissions, hazardous materials, and environmental accidents (Chow \& Chen, 2012; Delmas et al., 2013). These achievements are indirectly linked to customer satisfaction through the latter's concern for environmental protection. Moreover, firms may showcase their environmental performance for regulatory compliance or legitimacy purposes despite limited market orientation. Beyond these uses, firms are expected to lead a CA when they convert environmental capabilities implanted into EI. This is mainly because EI provides the biggest opportunity for companies to create competitive competencies from their proactive environmental investments (Orsato, 2006; Reinhardt, 1998). Eventually, these firms gain a market differentiation advantage through their superior green products or superior environmental reputation (Ambec \& Lanoie, 2008; Porter \& van der Linde, 1995). Likewise, ENC, through better processes in operations and manufacturing, may reduce operating costs (Ambec \& Lanoie, 2008; Porter \& van der Linde, 1995), thus granting a cost advantage. Therefore, building strong EI should be the top priority for manufacturers, given its mediating ability to realise CAs from environmental management.

Table 6

Mediation analysis results

\begin{tabular}{|c|c|c|c|c|c|c|}
\hline \multirow[b]{2}{*}{ Hypotheses } & \multirow[b]{2}{*}{ Path } & \multicolumn{4}{|c|}{ Indirect effects } & \multirow[b]{2}{*}{ Results } \\
\hline & & Beta & $\begin{array}{c}\text { Standard } \\
\text { error }\end{array}$ & t-value & p-value & \\
\hline $\mathrm{H} 4 \mathrm{a}$ & $\mathrm{ESF} \rightarrow \mathrm{EI} \rightarrow \mathrm{CA}$ & .353 & 0.060 & $5.920 * * *$ & .000 & Supported \\
\hline $\mathrm{H} 4 \mathrm{~b}$ & $\mathrm{ESV} \rightarrow \mathrm{EI} \rightarrow \mathrm{CA}$ & .146 & 0.062 & $2.337^{*}$ & .019 & Supported \\
\hline
\end{tabular}

Note: $* \mathrm{p} \leq .05, * * \mathrm{p} \leq .01, * * * \mathrm{p}<.0001 . \mathrm{ESF}=$ environmental strategic focus; ESV=environmental shared vision; EI=environmental innovation; $\mathrm{CA}=$ competitive advantage. 
Ultimately, manufacturers with superior EI tend to derive CAs from their achievements in environmental protection. Underpinned by the RBV (Hart, 1995; Hart \& Dowell, 2011; Sharma \& Vredenburg, 1998), the mediating role of EI found in this study provides evidence that through such innovations, competitive capabilities arise from manufacturers' environmental strategies. In addition, according to the ecoefficiency concept (Figge \& Hahn, 2012; Schaltegger \& Synnestvedt, 2002; Wagner \& Schaltegger, 2004), the mediating effect establishes EI as the key foundation behind value-based environmental strategies.

\section{IMPLICATIONS AND CONCLUSION}

The current study proposed and empirically examined the antecedents of CA from an environmental standpoint. The extant literature has largely focused on evaluating the impact of environmentally derived competitive capabilities on economic performance. Going beyond this view, we articulated the concepts of an environmentdriven shared vision and strategic focus and posited them as sources of dynamic capabilities that help firms maintain or enhance their competitiveness. Empirical evidence has thus far failed to validate ESV and environmental management support as environmental capabilities, despite high adoption of these practices among environmentally proactive manufacturers. In this regard, our findings reveal that ESF and ESV serve as environmental capabilities that drive EI. These outcomes, therefore, offer useful insights for future research to examine the conditions necessary for these constructs to act as environmental capabilities.

Our findings also provide valuable information for manufacturers in crafting their corporate competitive strategies, policies, and action plans. The direct and indirect roles of EI in fostering CAs suggest that manufacturers should prioritise their environmental activities by enhancing innovation outcomes to achieve a successful green business status.

Additionally, EI's mediating mechanism puts forth a strong justification for manufacturers to invest in environmental efforts. This is achievable through a wellcrafted environmental strategy and a shared vision within the organisation to ensure that strengths generated from environmental protection practices are translated into EIs. As such, manufacturers should capitalise on green design and green processes for their competitive strategies to achieve financial goals while also fulfilling environmental accountability expectations through environmental performance. This finding is therefore useful to manufacturers in addressing the conflicts between demands for environmental protection and demands for economic returns.

Finally, the findings of this study highlight the possibility for manufacturers to remain competitive by improving efficiency and effectiveness via the integration of environmental considerations at the strategic level. These measures could include the effective use of environmental information, 
adoption of eco-control systems, alignment of work culture to environmental directions, and employee empowerment through training programmes that promote environmental learning and creativity. Ultimately, the benefits of an environmental strategic focus and shared vision would be converted into environmental innovation and competitive advantage as a result of the direct effects as well as the indirect effect of environmental innovation in the relationship between environmental strategic focus and shared vision on competitive advantage.

\section{ACKNOWLEDGEMENT}

This research was supported by the Putra Grant (grant no. 9590300), Universiti Putra Malaysia. The authors would like to acknowledge the comments and suggestions given by the anonymous reviewers that have significantly improved the quality of our work.

\section{REFERENCE}

Ambec, S., Cohen, M. A., Elgie, S., \& Lanoie, P. (2013). The porter hypothesis at 20: Can environmental regulation enhance innovation and competitiveness? Review of Environmental Economics and Policy, 7(1), 2-22.

Ambec, S., \& Lanoie, P. (2008). Does it pay to be green? A systematic overview. Academy of Management Perspectives, 22(4), 45-62. https:// doi.org/10.5465/amp.2008.35590353

Aragón-correa, J. A., Hurtado-Torres, N. E., Sharma, S., \& García-Morales, V. J. (2008). Environmental strategy and performance in small firms: A resource-based perspective. Journal of Environmental Management, 86(1), 88-103. https://doi.org/10.1016/j.jenvman.2006.11.022
Armbruster, H., Bikfalvi, A., Kinkel, S., \& Lay, G. (2008). Organizational innovation: The challenge of measuring non-technical innovation in large-scale surveys. Technovation, 28(10), 644-657. https://doi.org/10.1016/j. technovation.2008.03.003

Arundel, A., \& Kemp, R. (2009). Measuring ecoinnovation. UNU-Merit. http://collections.unu. edu/eserv/UNU:324/wp2009-017.pdf

Banerjee, S. B. (2002). Corporate environmentalism: The construct and its measurement. Journal of Business Research, 55(3), 177-191.

Banerjee, S. B., Iyer, E. S., \& Kashyap, R. K. (2003). Corporate environmentalism: Antecedents and influence of industry type. Journal of Marketing, 67(2), 106-122. https://doi.org/10.1509/ jmkg.67.2.106.18604

Barney, J. B. (1991). Firm resources and sustained competitive advantage. Journal of Management, 17(1), 99-120. https://doi. org/10.1177/014920639101700108

Barney, J. B. (2001). Resource-based theories of competitive advantage: A ten-year retrospective on the resource-based view. Journal of Management, 27(6), 643-650. https://doi. org/10.1177/014920630102700602

Bradley, W., \& Henseler, J. (2007, December 3-5). Modeling reflective higher-order constructs using three approaches with PLS path modeling: A Monte Carlo comparison. ANZMAC 2007: Reputation, Responsibility, Relevance, Dunedin, New Zealand

Buysse, K., \& Verbeke, A. (2003). Proactive environmental strategies: A stakeholder management perspective. Strategic Management Journal, 24(5), 453-470. https://doi.org/10.1002/ smj.299

Camisón-Zornoza, C., Lapiedra-Alcamí, R., SegarraCiprés, M., \& Boronat-Navarro, M. (2004). A meta-analysis of innovation and organizational 
size. Organization Studies, 25(3), 331-361. https://doi.org/10.1177/0170840604040039

Chang, C.-H. (2011). The influence of corporate environmental ethics on competitive advantage: The mediation role of green innovation. Journal of Business Ethics, 104(3), 361-370. https://doi. org/10.1007/s10551-011-0914-x

Chen, Y. S. (2008). The driver of green innovation and green image - Green core competence. Journal of Business Ethics, 81(3), 531-543. https://doi. org/10.1007/s10551-007-9522-1

Chen, Y. S., Chang, C.-H., Yeh, S.-L., \& Cheng, H. I. (2015). Green shared vision and green creativity: The mediation roles of green mindfulness and green self-efficacy. Quality \& Quantity, 49(5), 1169-1184. https://doi.org/10.1007/s11135014-0041-8

Chen, Y. S., Lai, S. B., \& Wen, C. T. (2006). The influence of green innovation performance on corporate advantage in Taiwan. Journal of Business Ethics, 67(4), 331-339. https://doi. org/10.1007/s10551-006-9025-5

Cheng, C. C., \& Shiu, E. C. (2012). Validation of a proposed instrument for measuring ecoinnovation: An implementation perspective. Technovation, 32(6), 329-344. https://doi. org/10.1016/j.technovation.2012.02.001

Cheng, C. C., Yang, C.-1., \& Sheu, C. (2014). The link between eco-innovation and business performance: A Taiwanese industry context. Journal of Cleaner Production, 64, 81-90. https://doi.org/10.1016/j.jclepro.2013.09.050

Chin, W. W. (1998). Issues and opinion on structural equation modeling. MIS Quarterly, 22(1), viixvi.

Chin, W. W. (2010). How to write and report PLS analysis. In V. V. Esposito, W. W. Chin, J. Henseler \& H. Wang (Eds.), Handbook of partial least squares: Concepts, methods and applications. Springer.
Chiou, T.-Y., Chan, H. K., Lettice, F., \& Chung, S. H. (2011). The influence of greening the suppliers and green innovation on environmental performance and competitive advantage in Taiwan. Transportation Research Part E: Logistics and Transportation Review, 47(6), 822836. https://doi.org/10.1016/j.tre.2011.05.016

Chow, W. S., \& Chen, Y. (2012). Corporate sustainable development: Testing a new scale based on the mainland chinese context. Journal of Business Ethics, 105(4), 519-533. https://doi.org/10.1007/ s10551-011-0983-x

Coff, R. W. (1999). When competitive advantage doesn't lead to performance: The resourcebased view and stakeholder bargaining power. Organization Science, 10(2), 119-133.

Coombs, J. E., \& Bierly, P. E. (2006). Measuring technological capability and performance. R\&D Management, 36(4), 421-438. https:/doi. org/10.1111/j.1467-9310.2006.00444.x

Cortez, M. A., \& Cudia, C. P. (2010). The impact of environmental innovations on financial performance: The case of Japanese automotive and electronics companies. Journal of International Business Research, 9(SI. 1), 33-47.

Delmas, M., Etzion, D., \& Nairn-Birch, N. (2013). Triangulating environmental performance: What do corporate social responsibility ratings really capture? The Academy of Management Perspectives, 27(3), 255-267. https://doi. org/10.5465/amp.2012.0123

Dost, M., Pahi, M. H., Magsi, H. B., \& Umrani, W. A. (2019). Effects of sources of knowledge on frugal innovation: Moderating role of environmental turbulence. Journal of Knowledge Management, 23(7), 1245-1259. https://doi.org/10.1108/JKM01-2019-0035

Eltayeb, T. K., Zailani, S., \& Ramayah, T. (2011). Green supply chain initiatives among certified companies in Malaysia and environmental sustainability: Investigating the outcomes. 
Resources, Conservation and Recycling, 55(5), 495-506. https://doi.org/10.1016/j. resconrec.2010.09.003

Figge, F., \& Hahn, T. (2012). Is green and profitable sustainable? Assessing the trade-off between economic and environmental aspects environmental performance. International Journal of Production Economics, 140, 92-102. https://doi.org/10.1016/j.ijpe.2012.02.001

Falk, R. F., \& Miller, N. B. (1992). A primer for soft modeling. University of Akron Press.

Fernando, Y., Jabbour, C. J. C., \& Wah, W. X. (2019). Pursuing green growth in technology firms through the connections between environmental innovation and sustainable business performance: Does service capability matter? Resources, Conservation and Recycling, 141, 8-20. https:// doi.org/10.1016/j.resconrec.2018.09.031

Fornell, C., \& Larcker, D. F. (1981). Evaluating structural equation models with unobservable variables and measurement error. Journal of Marketing Research, 18(1), 39-50. https://doi. org/10.2307/3151312

Forsman, H. (2013). Environmental innovations as a source of competitive advantage or vice versa? Business Strategy and the Environment, 22(5), 306-320. https://doi.org/10.1002/bse.1742

Gastwirth, J. L., Gel, Y. R., \& Miao, W. (2009). The impact of Levene's test of equality of variances on statistical theory and practice. Statistical Science, 24(3), 343-360. https://doi.org/10.1214/09STS301

Grekova, K., Bremmers, H. J., Trienekens, J. H., Kemp, R. G. M., \& Omta, S. W. F. (2013). The mediating role of environmental innovation in the relationship between environmental management and firm performance in a multistakeholder environment. Journal on Chain and Network Science, 13(2), 119-137. https://doi. org/10.3920/JCNS2013.1003
Guenther, E., \& Hoppe, H. (2014). Merging limited perspectives. Journal of Industrial Ecology, 18(5), 689-707. https://doi.org/10.1111/ jiec. 12125

Hair, J. F., Hollingsworth, C. L., Randolph, A. B., \& Chong, A. Y. L. (2017). An updated and expanded assessment of PLS-SEM in information systems research. Industrial Management \& Data Systems, 117(3), 442-458. https://doi.org/10.1108/IMDS-04-2016-0130

Hair, J. F., Hult, G. T. M., Ringle, C., \& Sarstedt, M. (2016). A Primer on Partial Least Squares Structural Equation Modeling (PLS-SEM) (2nd ed.). Sage.

Hair, J. F., Ringle, C. M., \& Sarstedt, M. (2013). Partial least squares structural equation modeling: Rigorous applications, better results and higher acceptance. Long range planning, 46(1-2), 1-12.

Hart, S. L. (1995). A natural-resource-based view of the firm. The Academy of Management Review, 20(4), 986-1014. https://doi.org/10.2307/258963

Hart, S. L., \& Dowell, G. (2011). A natural-resourcebased view of the firm: Fifteen years after. Journal of Management, 37(5), 1464-1479. https://doi.org/10.1177/0149206310390219

Henseler, J., Ringle, C. M., \& Sinkovics, R. R. (2009). The use of partial least squares path modeling in international marketing. In R. S. Rudolf \& N. G. Pervez (Eds.), New challenges to international marketing (Vol. 20, pp. 277-319). Emerald Jai.

Henseler, J., Ringle, C. M., \& Sarstedt, M. (2015). A new criterion for assessing discriminant validity in variance-based structural equation modeling. Journal of the academy of marketing science, 43(1), 115-135. https://doi.org/10.1007/ s11747-014-0403-8

Judge, W. Q., \& Douglas, T. J. (1998). Performance implications of incorporating natural environmental issues into the strategic planning process: An empirical assessment. Journal of 
Management Studies, 35(2), 241-262. https:// doi.org/10.1111/1467-6486.00092

Karagozoglu, N., \& Lindell, M. (2000). Environmental management: testing the winwin model. Journal of Environmental Planning and Management ,43, 817-829. https://doi. org/10.1080/09640560020001700

Kesidou, E., \& Demirel, P. (2012). On the drivers of eco-innovations: Empirical evidence from the UK. Research Policy, 41(5), 862-870. https:// doi.org/10.1016/j.respol.2012.01.005

King, A., \& Lenox, M. (2001). Does it really pay to be green? An empirical study of firm environmental and financial performance. Journal of Industrial Ecology, 5(1), 105-116. https://doi.org/10.1162/108819801753358526

Klassen, R. D., \& Whybark, D. C. (1999). Environmental management in operations: The selection of environmental technologies. Decision Sciences, 30(3), 601-631. https://doi. org/10.1111/j.1540-5915.1999.tb00900.x

Küçükoğlu, M. T., \& Pınar, R. İ. (2015). Positive influences of green innovation on company performance. Procedia-Social and Behavioral Sciences, 195, 1232-1237. https://doi. org/10.1016/j.sbspro.2015.06.261

Larwood, L., Falbe, C. M., Kriger, M. P., \& Miesing, P. (1995). Structure and meaning of organisational vision. Academy of Management Journal, 38(3), 740-769. https://doi.org/10.2307/256744

Lee, V.-H., Ooi, K.-B., Chong, A. Y.-L., \& Lin, B. (2013). A structural analysis of greening the supplier, environmental performance and competitive advantage. Production Planning \& Control: The Management of Operations, 26(2), 116-130. https://doi.org/10.1080/09537287.201 3.859324

Liao, Z. (2016). Temporal cognition, environmental innovation, and the competitive advantage of enterprises. Journal of Cleaner Production, 135,
1045-1053. https://doi.org/10.1016/j. jclepro.2016.07.021

Ma, H. (2000). Competitive advantage and firm performance. Competitiveness Review: An International Business Journal, 10(2), 15-32. https://doi.org/10.1108/eb046396

McCarthy, N., Rouse, W. B., \& Serban, N. (2015). Disentangling competitive advantage and superior performance and their roles in enterprise transformation. Journal of Enterprise Transformation, 5(2), 113-140. https://doi.org/1 $0.1080 / 19488289.2015 .104017$

McCloskey, J., \& Maddock, S. (1994). Environmental management: Its role in corporate strategy. Management Decision, 32(1), 27-32. https://doi. org/10.1108/00251749410050651

Newbert, S. L. (2007). Empirical research on the resource-based view of the firm: An assessment and suggestions for future research. Strategic Management Journal, 28(2), 121-146. https:// doi.org/10.1002/smj.573

Nishimura, A. (2014). Transforming cost design into environmentally conscious cost design in Japan: Likelihood and problems for further development. Journal of Management Control, 25(1), 55-75. https://doi.org/10.1007/ s00187-014-0190-x

O’Connell, D., Hickerson, K., \& Pillutla, A. (2011). Organizational visioning: An integrative review. Group \& Organization Management, 36(1), 103125. https://doi.org/10.1177/1059601110390999

OECD. (2005). Oslo manual: Guidelines for collecting and interpreting innovation data (3rd ed.). OECD Publishing.

Ong, T. S., Lee, A. S., Teh, B. H., \& Magsi, H. B. (2019). Environmental innovation, environmental performance and financial performance: Evidence from Malaysian environmental proactive firms. Sustainability, 11(12), 3494. https://doi.org/10.3390/su11123494 
Ong, T. S., Lee, A. S., Teh, B. H., Magsi, H. B., \& Ng, S. H. (2020). Environmental capabilities and environmental innovations of manufacturing firms in Malaysia. Indonesian Journal of Sustainability Accounting and Management, 1(1), 1-14. https://doi.org/10.28992/ijsam. v4i1.248

Orsato, R. J. (2006). Competitive environmental strategies: When does it pay to be green? California Management Review, 48(2), 127-143. https://doi.org/10.2307/41166341

Pearce, C. L., \& Ensley, M. D. (2004). A reciprocal and longitudinal investigation of the innovation process: The central role of shared vision in product and process innovation teams (PPITs). Journal of Organizational Behavior, 25(2), 259278. https://doi.org/10.1002/job.235

Peteraf, M. A. (1993). The cornerstones of competitive advantage: A resource-based view. Strategic Management Journal, 14(3), 179-191.

Peteraf, M. A., \& Barney, J. B. (2003). Unraveling the resource-based tangle. Managerial \& Decison Economics, 24(4), 309-323. https://oi. org/10.1002/mde. 1126

Podsakoff, P. M., MacKenzie, S. B., Lee, J.-Y., \& Podsakoff, N. P. (2003). Common method biases in behavioral research: A critical review of the literature and recommended remedies. Journal of Applied Psychology, 88(5), 879-903. https:// doi.org/10.1037/0021-9010.88.5.879

Porter, M. E. (1980). Industry structure and competitive strategy: Keys to profitability. Financial Analysts Journal, 36(4), 30-41.

Porter, M. E. (1981). The contributions of industrial organization to strategic management. Academy of Management Review, 6(4), 609-620. https:// doi.org/10.2307/257639

Porter, M. E., \& Kramer, M. R. (2006). Strategy and society: The link between competitive advantage and corporate social responsibility. Harvard Business Review, 84(12), 78-92.
Porter, M. E., \& Van der Linde, C. (1995). Green and competitive: Ending the stalemate. Harvard Business Review, 73(5), 120-134.

Pujari, D., Peattie, K., \& Wright, G. (2004). Organizational antecedents of environmental responsiveness in industrial new product development. Industrial Marketing Management, 33(5), 381-391. https://doi.org/10.1016/j. indmarman.2003.09.001

Reinhardt, F. L. (1998). Environmental product differentiation: Implicaitons for corporate strategy. California Management Review, 40(4), 43-73. https://doi.org/10.2307/41165964

Rennings, K., Ziegler, A., Ankele, K., \& Hoffmann, E. (2006). The influence of different characteristics of the EU environmental management and auditing scheme on technical environmental innovations and economic performance. Ecological Economics, 57(1), 45-59. https:// doi.org/10.1016/j.ecolecon.2005.03.013

Ong, T.S, Magsi, H. B., \& Burgess, T. F. (2019). Organisational culture, environmental management control systems, environmental performance of Pakistani manufacturing industry. International Journal of Productivity and Performance Management, 68(7), 1293-1322. https://doi.org/10.1108/IJPPM-05-2018-0187

Sarstedt, M., Ringle, C. M., Smith, D., Reams, R., \& Hair, J. F. (2014). Partial Least Squares Structural Equation Modeling (PLS-SEM): A useful tool for family business researchers. Journal of Family Business Strategy, 5(1), 105-115. https://doi. org/10.1016/j.jfbs.2014.01.002

Schaltegger, S., \& Synnestvedt, T. (2002). The link between 'green' and economic success: Environmental management as the crucial trigger between environmental and economic performance. Journal of Environmental Management, 65(4), 339-346. https://doi. org/10.1006/jema.2002.0555 
Schiederig, T., Tietze, F., \& Herstatt, C. (2012). Green innovation in technology and innovation management - An exploratory literature review. R\&D Management, 42(2), 180-192. https://doi. org/10.1111/j.1467-9310.2011.00672.x

Sezen, B., \& Çankaya, S. Y. (2013). Effects of green manufacturing and eco-innovation on sustainability performance. Procedia - Social and Behavioral Sciences, 99, 154-163. https:// doi.org/10.1016/j.sbspro.2013.10.481

Sharma, S., \& Vredenburg, H. (1998). Proactive corporate environmental strategy and the development of competitively valuable organizational capabilities. Strategic Management Journal, 19(8), 729-753. https://doi.org/10.1002/ (SICI) 1097-0266(199808)19:8<729::AIDSMJ967>3.0.CO;2-4

Shrivastava, P. (1995). Environmental technologies and competitive advantage. Strategic Management Journal, 16(S1), 183-200. https:// doi.org/10.1002/smj.4250160923

Sigalas, C., \& Economou, V. P. (2013). Revisiting the concept of competitive advantage: problems and fallacies arising from its conceptualization. Journal of Strategy and Management, 6(1), 6180. https://doi.org/10.1108/17554251311296567

Sigalas, C., Economou, V. P., \& Georgopoulos, N. B. (2013). Developing a measure of competitive advantage. Journal of Strategy and Management, 6(4), 320-342. https://doi.org/10.1108/JSMA03-2013-0015
Tsai, W., \& Ghoshal, S. (1998). Social capital and value creation: The role of intrafirm networks. Academy of Management Journal, 41(4), 464476. https://doi.org/10.2307/257085

Wagner, M., \& Schaltegger, S. (2004). The effect of corporate environmental strategy choice and environmental performance on competitiveness and economic performance: An empirical study of EU manufacturing. European Management Journal, 22(5), 557-572. https:// doi.org/10.1016/j.emj.2004.09.013

Walley, N., \& Whitehead, B. (1994). It's not easy being green. Harvard Business Review, 72(3), 46-51.

Wiengarten, F., Pagell, M., \& Fynes, B. (2013). ISO 14000 certification and investments in environmental supply chain management practices: identifying differences in motivation and adoption levels between Western European and North American companies. Journal of Cleaner Production, 56, 18-28. https://doi. org/10.1016/j.jclepro.2012.01.021

Zaccaro, S. J., \& Banks, D. (2001). Leadership, vision, and organizational effectiveness. In S. J. Zaccaro \& R. J. Klimoski (Eds.), The nature of organizational leadership: Understanding the performance imperatives confronting today's leaders (pp. 181-218). Jossey-Bass. 